\title{
Frequency of Toxoplasma gondii antibodies in tufted capuchin monkeys (Cebus apella nigritus) from an ecological station in the State of São Paulo, Brazil ${ }^{1}$
}

\author{
Rodrigo Costa da Silva ${ }^{2 *}$, Gustavo Puglia Machado², Tatiane Morosini de Andrade Cruvinel ${ }^{3}$ \\ Ciro Alexandre Cruvinel ${ }^{4}$ and Helio Langoni ${ }^{2}$
}

\begin{abstract}
Da Silva R.C., Machado G.P., Cruvinel T.M.A., Cruvinel C.A. \& Langoni H. 2013. Frequency of Toxoplasma gondii antibodies in tufted capuchin monkeys (Cebus apella nigritus) from an ecological station in the State of São Paulo, Brazil. Pesquisa Veterinária Brasileira 33(2):251-253. Departamento de Higiene Veterinária e Saúde Pública, Faculdade de Medicina Veterinária e Zootecnia, Universidade Estadual Paulista, Campus de Botucatu, Distrito de Rubião Júnior s/n, Botucatu, SP 18618-970, Brazil. E-mail: silva_rcd@yahoo.com.br

Toxoplasmosis is a worldwide zoonosis caused by Toxoplasma gondii, an obligate intracellular parasite protozoan. A large percentage of animals presents specific antibodies caused by a previous exposition, resulting in a chronic infection. Felides are the definitive hosts and the other warm-blooded animals, including primates, are the intermediate hosts. This study was aimed to determine the prevalence of T. gondii infection in free-living tufted capuchin monkeys (Cebus apella nigritus) from an ecological station located on Mata de Santa Teresa, Ribeirão Preto, SP, Brazil. T. gondii antibodies were analyzed by modified agglutination test (MAT) in serum samples of 36 tufted capuchin monkeys, considering eight as cut-off titer. From the studied animals, 3/36 (8.33\%; CI95\% 3.0-21.9\%) presented T. gondii antibodies, all with titer 32 . No significative difference was observed relating to the sex $(1 / 3$ male and $2 / 3$ female), and to the age $(1 / 3$ young and $2 / 3$ adult $)(P>0.05)$. Thus, these results demonstrate the presence of T. gondii antibodies in primates from São Paulo state.
\end{abstract}

INDEX TERMS: Toxoplasma gondii, natural infection, antibodies, Cebus apella nigritus, MAT, nonhuman primates.

RESUMO-- [Frequência de anticorpos anti-Toxoplasma gondii em macacos-prego (Cebus apella nigritus) de estação ecológica localizada no Estado de São Paulo.] A toxoplasmose é uma das zoonoses mais difundidas no mundo, causada pelo Toxoplasma gondii, um protozoário parasita intracelular obrigatório. Uma alta porcentagem de animais apresenta anticorpos específicos causados por exposição prévia, levando a uma infecção crônica. Os felídeos

\footnotetext{
${ }^{1}$ Received on July 3, 2012.

Accepted for publication on 8 de setembro de 2012.

${ }^{2}$ Departamento de Higiene Veterinária e Saúde Pública, Faculdade de Medicina Veterinária e Zootecnia, Universidade Estadual Paulista (Unesp), Campus Botucatu, Distrito de Rubião Júnior s/n, Botucatu, SP 18618-970, Brazil. *Corresponding author: silva_rcd@yahoo.com.br

${ }^{3}$ Hospital Veterinário, Centro Universitário Rio Preto (Unirp), Rodovia BR 153 Km 69, São José do Rio Preto, SP, Brazil.

${ }^{4}$ Ambientalvet - Consultoria Ambiental Veterinária, Rua Sebastião Pinto Brandão 1055, Jardim América, Bady Bassitt, SP 15115-000, Brazil.
}

são os hospedeiros definitivos e outros animais homeotérmicos, incluindo os primatas, são os hospedeiros intermediários. Este estudo objetivou determinar a prevalência da infecção por T. gondii em macacos-prego (Cebus apella nigritus) de vida livre da Estação Ecológica localizada na Mata de Santa Teresa, Ribeirão Preto, SP, Brasil. Anticorpos anti-T. gondii foram pesquisados pelo método de aglutinação direta modificada (MAT) em amostras de soro de 36 macacos-prego, utilizando-se o título oito como de corte. Dos animais estudados, 3/36 (8,33\%; IC95\% 3,0-21,9\%) apresentaram anticorpos anti-T. gondii, todos com título 32. Nenhuma diferença significativa $(P>0,05)$ foi observada com relação ao sexo (1/3 machos e $2 / 3$ fêmeas), e à idade ( $1 / 3$ jovens e $2 / 3$ adultos). Assim, estes resultados demonstram alta prevalência de anticorpos anti-T. gondii em primatas no estado de São Paulo.

TERMOS DE INDEXAÇ̃̃O: Toxoplasma gondii, infecção natural, anticorpos, Cebus apella nigritus, MAT, primatas não humanos. 


\section{INTRODUCTION}

Toxoplasma gondii, an obligate intracellular apicomplexan parasite protozoan, is widely distributed and can infect many species of warm-blooded animals; thus, it is considered a significant zoonotic pathogen (Acha \& Szyfres 2003, Weiss \& Dubey 2009, Cenci-Conga et al. 2011). Members of the cat family are the definitive hosts, and domestic cats take importance for their proximity with humans (Dubey et al. 1995). The parasite can infect a variety of cell types from a wide range of mammals and birds throughout the world, including humans and nonhuman primates. Monkeys can be infected with T. gondii (McKissick et al. 1968); it has been commonly described in acute form in New World monkeys (Dietz et al. 1997, Epiphanio et al. 2003). Monkeys from the old World seem fairly resistant to infection with this parasite, while individuals from the New World are highly susceptible (Cunningham et al. 1992, Dietz et al. 1997). Toxoplasmosis in nonhuman primates can cause acute disseminated infection with acute interstitial pneumonia and focal hepatocellular necrosis, fever, anorexia, Increased, breathing, frequency, vomitus and diarrhea (Anderson \& McClure 1993, Spencer et al. 2004, Andrade et al. 2007). The prevalence in monkeys range from $1.4 \%$ in Macaca fascicularis from China (Li et al. 2010) to 63.3\% in Saimiri spp. from Brazil (Ferraroni \& Marzochi 1980).

It has been suggested that the evolution of monkeys on a landmass with no felids, the definitive Toxoplasma hosts, has precluded them from developing a protective response to $T$. gondii (Cunningham et al. 1992). Based on this, some nonhuman primates can be considered sentinels for human infection (Leite et al. 2008). The animals can be infected by bottom layer (dead leaves, wood chips, and soil), eating rodents, insects living in pens contaminated by ground material or feeding stuff (the monkeys were frequently offered giant meal ,worms stored on peat moss). The main food items consisted of fresh fruit and vegetables, which had been cleaned in tap water prior to offering to the monkeys. In addition marmosets ate pellets, hard boiled eggs, milk products, vitamins and calcium and trace elements supply (Dietz et al. 1997).

Tufted capuchin monkeys, Cebus apella nigritus Linnaeus, 1758 (Primata, Cebidae, Platyrrhinae) have the largest geographical distribution among all species of Neotropical primates. They are found ranging the East of The Andes to South $27^{\circ}$, ranging sea level to $2,700 \mathrm{~m}$ in Colombia (Freese \& Oppenheimer 1981, Fragaszy et al. 1990, Auricchio 1995). This species lives in a large variety of florestal types, including inundable rainforest or not, primary or secondary forests, caatinga, palms, fields and fens, with an omnivorous alimentation. They feed fruits (60\%), seeds (7\%), chestnut, flowers, nectar, fungus, sap, eggs, insects, arachnids, small vertebrates and some species of oyster and crabs found in costal regions. They hunt many times in 24 hours, explaining the risk of this specie to be infected with T. gondii (Auricchio 1995). In Brazil, the prevalence for toxoplasmosis in this species range from 18.2\% (Nery-Guimarães \& Franken 1971) to 60\% (Sanchis et al. 1972).

Thus, the present study aimed to determine the prevalence of T. gondii infection in tufted capuchin monkeys ( $\mathrm{Ce}$ bus apella nigritus) from São Paulo State, Brazil.

\section{MATERIALS AND METHODS}

This study included 36 animals of three groups of free-living tufted capuchin monkeys (Cebus apella nigritus). These groups live in Mata Santa Teresa, Ecological Station from Ribeirão Preto, an hemi-urban State Reserve, located in South region of Ribeirão Preto, São Paulo State $\left(21^{\circ} 14^{\prime} \mathrm{S}, 47^{\circ} 55^{\prime} \mathrm{W} ; 570 \mathrm{~m}\right.$ over than sea level). It has a mesophyll forest, hardwood, in regeneration, with 158.21 hectares. The height of the dossal range between 20 to $25 \mathrm{~m}$, the underground is dense, with numerous lianas (Siemers 2000). Mata de Santa Teresa is rounded by sugar cane plantations and surrounded by many small houses. The climate is seasonal, with a cold dry season and another rainy hot. The primate species living there are Cebus apella and Callithrix penicillata. The present study was approved by Brazilian Institute of the Environment (IBAMA), license 218/2004-CGFAU/LIC, Process 02027.002705/2000-05.

The animals were captured in Tomahawk traps located in specific areas that the animals stayed for more time. All traps were disposed with fruits inside. The animals were moved to a contention cage to facilitate the management and the chemical restraint (10mg. $\mathrm{kg}^{-1}$ ketamine intramuscular and $2 \mathrm{mg} \cdot \mathrm{kg}^{-1}$ xilazine intramuscular, or $1 \mathrm{mg}^{-1} \mathrm{~kg}^{-1}$ midazolan intramuscular) of the animals. After the chemical contention, blood samples were collected by femoral vein punction with sterile Vacutainer ${ }^{\circledR}$ system. Blood samples were kept in room temperature for two hours to retain the coagulum. The samples were centrifuged in $1,600 \mathrm{xg}$ for 10 $\mathrm{min}$, and the serum samples were separated in a sterile microtube and kept to $-20^{\circ} \mathrm{C}$ until the serology.

Serum samples were analyzed for Toxoplasma gondii antibodies by modified agglutination test (MAT), using homemade formalin-fixed antigen produced by the inoculation of RH strain (genotype I) and TG180 murine sarcomatous cells (ATCC CCRFS-180 II) in Swiss female mice (Desmonts \& Remington 1980). Samples were twice diluted from 1:8 dilution. A clear-cut button-shaped deposit of parasite suspension at the bottom of the well was interpreted as negative reaction and a complete carpet of agglutinated organisms was considered positive. Positive and negative controls were obtained by previous serology of chronic infected mice. The controls were used, considering titer eight as cut-off titer.

The association among epidemiological data and the results of serology were analyzed by Chi-Square or Fisher's exact test, considering the significance level $(\alpha)$ as $5 \%$ (Triola 2005). All tests were processed in EpiInfo ${ }^{\mathrm{TM}}$ v.3.5.1. software.

\section{RESULTS AND DISCUSSION}

Toxoplasma gondii antibodies were found in 3/36 (8.33\%; CI95\% 3.0-21.9\%) tufted capuchin monkeys, all with titer 32 . The prevalence found in this study was lower than that observed by Garcia et al. (2005) in Paraná, Brazil [13/43 (30.2\%)], Sanchis et al. (1972) in São Paulo, Brazil [3/5 (60\%)], and Leite et al. (2008) in Mato Grosso do Sul, Brazil [4/13 (30.8\%), but higher than $0 \%(0 / 10)$ observed by Cadavid et al. (1991) in Medellín, Colombia. The low prevalence in the present study could be due the low or dispersed distribution of oocysts of $T$. gondii shed by wild felids in the environmental where monkeys were exposed, being infected by the ingestion of fruits, insects, or tissue cysts by predation of birds and rodents (Leite et al. 2008).

Comparing with other studies, using other nonhuman primates than tufted capuchin monkeys, different prevalence were observed by Garcia et al. (2005) studying black and golden howler monkeys, Alouatta caraya $(3 / 17,17.6 \%)$, by Cadavid et al. (1991) studying Cebus albifrons (9/22, 40.9\%) 
Table 1. Association between the epidemiological data and the presence of Toxoplasma gondii antibodies in tufted capuchin monkeys (Cebus apella nigritus)

\begin{tabular}{lcccccc}
\hline Variable & & $\mathrm{N}^{\mathrm{a}}$ & MAT $^{\mathrm{b}}$ & Variable (\%); IC95\% $^{\mathrm{C}}$ & $\mathrm{OR}_{(\mathrm{CI} 95 \%)^{\mathrm{d}}}$ & $P^{\mathrm{e}}$ \\
\hline \multirow{2}{*}{ Sex } & Male & 20 & 1 & $5.0 ; 1.1-23.8$ & $0.4(0.0-4.5)$ & 0.42 \\
& Female & 16 & 2 & $12.5 ; 3.8-36.4$ & & \\
\multirow{2}{*}{ Age } & Young & 20 & 1 & $5.0 ; 1.1-23.8$ & $0.4(0,0-4.5)$ & 0.42 \\
& Adult & 16 & 2 & $12.5 ; 3.8-36.4$ & &
\end{tabular}

${ }^{\mathrm{a}} \mathrm{N}=$ Number of analyzed animals, ${ }^{\mathrm{b}} \mathrm{MAT}=$ Positive animals for modified agglutination test (titer $\geq 8$ ), ${ }^{\mathrm{c}}$ Frequency of positive animals based on the studied variables (confidence interval $=95 \%$ ), ${ }^{\mathrm{d}} \mathrm{OR}=$ Odds ratio, ${ }^{\mathrm{e}} P$ $=P$ value to $\mathrm{a}=5 \%$.

and C. capucinus $(2 / 15,13.3 \%)$, by Sanchis et al. (1972) studying Alouatta fusca (5/12, 41.7\%), by Li et al. (2010) studying bred cynomolgus monkeys, Macaca fascicularis (5/360, 1.4\%) in China, and by Ekanayake et al. (2004) studying toque macaques, $M$. sinica, $(21 / 170,12 \%)$ in Sri Lanka.

No significant difference was observed regarding the sex, where $1 / 3(33.3 \%)$ were male and $2 / 3(66.7 \%)$ female $(P>0.05)$. Concomitantly, the age also did not present significant difference, with $1 / 3(33.3 \%)$ were young (one or over than one year of age) and 2/3 (66.7\%) adult (less than one year of age) $(P>0.05)$ (Table 1). Probably, other variables, i.e., type of food, water source or rodents' predatism could present significative association, but these information were not available. These data corroborate with those presented by Garcia et al. (2005), and in these colonies the distribution of the infection could be associated to other epidemiological data.

Both Ekanayake et al. (2004) and Garcia et al. (2005) observed significant risk of the occurrence of toxoplasmosis in humans by the analysis of nonhuman primate serum samples, considering these primates as sentinels to human infection, once they have access to human places, and eating fruits and vegetables contaminated with oocysts from the soil and demonstrate the risk to human infection by these type of food in urban, rural and wild areas. In some urban, rural and wild areas, some of them indigenous, nonhuman primates are hunted and used as food, one more example of the risk to human infection and importance as sentinels. So, the ingestion of infective forms through inadequately cooked game meat, as well as handling carcasses of wild game should be considered a potential source of infection (Bóia et al. 2008). Many wild animals are considered sentinels for toxoplasmosis, i.e., armadillos, coatis, marsupials and others (Acha \& Szyfres 2003). Probably, the presence of Neotropical felids can facilitate the infection of these animals, and feces from these animals could be the main source of transmission to nonhuman primates.

In conclusion, these results demonstrate the presence of T. gondii antibodies in primates from São Paulo state.

\section{REFERENCES}

Acha P. \& Szyfres B. 2003. Zoonosis y enfermedades transmisibles comunes al hombre y a los animales. 3a ed. Publicación Científica, Organización Panamericana de la Salud. 480p.

Anderson D.C. \& McClure H.M. 1993. Toxoplasmosis, p .63-69. In: Jones T.C., Mohr U. \& Hunt R.D. (Eds), Nonhuman Primates. II. Monographs on pathology of laboratory animals. Springer, Berlin.

Andrade M.C.R., Coelho J.M.C.O., Amendoeira M.R.R., Vicente R.T., Cardoso C.V.P., Ferreira P.C.B. \& Marchevsky R.S. 2007. Toxoplasmosis in squirrel monkeys: histological and immunohistochemical analysis. Ciêcia Rural 37(6):1724-1727.

Auricchio P. 1995. Primatas do Brasil. Terra Brasilis, São Paulo. 168p.

Bóia M.N., Carvalho-Costa F.A., Sodré F.C., Pinto G.M.T. \& Amendoeira M.R. R. 2008. Seroprevalence of Toxoplasma gondii infection among indian people living in Iauareté, São Gabriel da Cachoeira, Amazonas, Brazil. Revta Inst. Med. Trop. São Paulo, 50(1):17-20.

Cadavid A.P., Cañas L., Estrada J.J. \& Ramirez L.E. 1991. Prevalence of anti-Toxoplasma gondii antibodies in Cebus spp in the Santa Fe Zoological Park of Medellín, Colombia. J. Med. Primatol. 20(5):259-261.

Cenci-Goga B.T., Rossitto P.V., Sechi P., McCrindle C.M.E. \& Cullor J.S. 2011. Toxoplasma in animals, food, and humans: an old parasite of new concern. Foodborne Path. Dis. 8(7):751-762.

Cunningham A.A., Buxton D. \& Thomson K.M. 1992. An epidemic of toxoplasmosis in a captive colony of squirrel monkeys (Saimiri sciureus). J. Comp. Pathol. 107:207-219.

Desmonts G. \& Remington J.S. 1980. Direct agglutination test for diagnosis of Toxoplasma infection: Method for increasing sensitivity and specificity. J. Clin. Microbiol. 11:562-568.

Dietz H.H., Henriksen P., Bille-Hansen V. \& Henriksen S.A. 1997. Toxoplasmosis in a colony of New World monkeys. Vet. Parasitol. 68:299-304.

Dubey J.P., Lappin M.R. \& Thulliez P. 1995. Long term antibody responses of cat fed Toxoplasma gondii tissue cysts. J. Parasitol. 81:887-893.

Ekanayake D.K., Rajapakse R.P.V.J., Dubey J.P. \& Dittus W.P.J. 2004. Seroprevalence of Toxoplasma gondii in wild toque macaques (Macaca sinica) at Polonnaruwa, Sri Lanka. J. Parasitol. 90:870-871.

Epiphanio S., Sinhorini I.L. \& Catão-Dias J.L. 2003. Pathology of toxoplasmosis in captive New World primates. J. Comp. Pathol. 129:196-204.

Ferraroni J.J. \& Marzochi M.C.A. 1980. Prevalência da infecção pelo Toxoplasma gondii em animais domésticos, silvestres e grupamentos humanos da Amazônia. Mem. Inst. Oswaldo Cruz 75(1/2):99-109.

Fragaszy D.M., Visalberghi E. \& Robinson J.G. 1990. Variability and adaptability in the genus Cebus. Folia Primatol. 54:114-118.

Freese C.H. \& Oppenheimer J.R. 1981. The capuchin monkey, genus Cebus, p.331-391. In: Coimbra-Filho J.I. \& Mittermeier R.A. (Eds), Ecology and Behavior of Neotropical Primates. Academia Brasileira de Ciências, Rio de Janeiro.

Garcia J.L., Svoboda W.K., Chryssafidis A.L., Malanski L.S., Shiozawa M.M., Aguiar L.M., Teixeira G.M., Ludwig G., Silva L.R., Hilst C. \& Navarro I.T. 2005. Sero-epidemiological survey for toxoplasmosis in wild New World monkeys (Cebus spp., Alouatta caraya) at the Paraná river basin, Paraná State, Brazil. Vet. Parasitol. 133:307-311.

Leite T.N.B., Maja T.A., Ovando T.M., Cantadori D.T., Schimidt L.R., Guércio A.C., Cavalcanti Á., Lopes F.M.R., Cunha I.A.L. \& Navarro I.T. 2008. Ocorrência de infecção por Leishmania spp. e Toxoplasma gondii em macacos-prego (Cebus apella) de Campo Grande, MS. Rev. Bras. Parasitol. Vet. 17(Supl.1):307-310.

Li H.-L., Yan C., Li J., Ai L., Zhou D.-H., Yuan Z.-G., Lin R.-Q., Zhao G.-H. \& Zhu X.-Q. 2010. Seroprevalence of Toxoplasma gondii in bred cynomolgus monkeys (Macaca fascicularis) in China. J. Parasitol. 96(4):807-808.

McKissick G.E., Ratcliffe H.L. \& Koesmer A. 1968. Enzootic toxoplasmosis in caged squirrel monkeys (Saimiri sciureus). Vet. Pathol. 5: 538-541.

Nery-Guimarães F., Franken A.J. 1971. Toxoplasmose em primatas não humanos, II - Tentativas de infecções experimentais em Macaca mulatta, Cebus apella e Callithrix jacchus; e pesquisa de anticorpos em várias espécies de Platyrrhinus. Mem. Inst. Oswaldo Cruz 69(2):97-118.

Sanchis F.S., Jamra L.F., Guimarães E.C. \& Deane M.P. 1972. Toxoplasmose espontânea em animais domésticos e silvestres, em São Paulo. Rev. Inst. Med. Trop., São Paulo, 14(5):314-320.

Siemers B.M. 2000. Seasonal variation in food resource and forest strata use by brown capuchin monkeys (Cebus apella) in a disturbed forest fragment. Folia Primatol. 71:181-184.

Spencer J.A., Joiner K.S., Hilton C.D., Dubey J.P., Toivio-Kinnucan M., Minc J.K. \& Blagburn B.L. 2004. Disseminated toxoplasmosis in a captive ring-tailed lemur (Lemur catta). J. Parasitol. 90(4):904-906.

Triola M.F. 2005. Introdução à Estatística. 9a ed. LTC, Rio de Janeiro. 682p.

Weiss L.M. \& Dubey J.P. 2009. Toxoplasmosis: A history of clinical observations. Int. J. Parasitol. 39:895-901. 